\title{
11 Russia in the Global Parliamentary Moment, 1905-1918: Between a Subaltern Empire and an Empire of Subalterns
}

\section{Introduction}

The establishment of the legislative State Duma (17 October 1905) ${ }^{1}$ and the adoption of the Fundamental Laws of the Russian Empire (23 April 1906) by Tsar Nicholas II during the Revolution of 1905-1907 seemed to make Russia a constitutional state. In 1907, Vladimir Matveevich Gessen and Boris Emmanuilovich Nol'de, two prominent liberal legal scholars, listed Russia, together with Persia and Montenegro, as the new constitutional states in their comprehensive collection of contemporary constitutions. Articulating a popular progressive view, they claimed that the failures of the Russo-Japanese War (1904-1905) unmasked the inefficiency of bureaucratic autocracy, spreading the critical attitudes to the ancien régime beyond intellectual circles and transforming them into a broad liberation movement across the whole country. ${ }^{2}$

Few intellectuals, however, viewed the Duma as a parliament equal to its Western counterparts. It occupied a subordinate position to the State Council, which was reformed into a partly appointed upper chamber, and did not control the cabinet, which contributed to the term "sham constitutionalism". ${ }^{3}$ The non-universal, indirect, and unequal elections were further limited with the

1 All dates are given in the Old Style, which is according to the Julian calendar.

2 V. M. Gessen and B. E. Nol'de (eds.), Sovremennye Konstitutsii: Sbornik Deistvuiushchikh Konstitutsionnykh Aktov [Contemporary Constitutions: A Collection of Constitutional Acts in Force], vol. 2: Federatsii i Respubliki [Federations and Republics], Saint Petersburg: Pravo, 1907, pp. 565-566.

3 M. Weber, "Russlands Übergang zum Scheinkonstitutionalismus", Archiv für Sozialwissenschaft und Sozialpolitik 23 (1906) 1, Beilage, pp. 165-401.

Note: The research for this chapter was done as part of the project "ENTPAR: Entangled Parliamentarisms: Constitutional Practices in Russia, Ukraine, China and Mongolia, 1905-2005", which received funding from the European Research Council (ERC) under the European Union's Horizon 2020 research and innovation programme (grant agreement No. 755504). 
dissolution of the Second Duma on 3 June 1907. Nol'de nevertheless stressed that the Russian Empire could be called a constitutional state and termed the State Duma the first normally functioning parliament in Russia, implying the country's connection to Western constitutional modernity. ${ }^{4}$ Indeed, the Duma not only became an important part of the empire's governance and politics but also reconfigured the political topology of the empire by bringing non-Russian and non-elite deputies into the government. ${ }^{5}$

Despite their criticism of the Duma, liberal and moderate socialist and nationalist thinkers generally supported parliamentarism. Right and left radicals, by contrast, questioned the very necessity of a parliament. The right argued that Russia was self-sufficient and did not need Western democracy; the left rejected parliaments, claiming them a part of class exploitation and oppressive state machinery, and called for direct rule of the toilers to represent an alternative democratic modernity. In Osnovy Konstitutsionnogo Prava [Foundations of Constitutional Law], his 1916 dissertation, Gessen juxtaposed democratization, understood as the maximization of popular participation, and contemporary parliamentarism. Suggesting that the latter contradicted the idea of popular sovereignty, which he rejected, Gessen remained optimistic about the capacity of European constitutionalism to safeguard against democratic despotism. ${ }^{6}$

The Bolshevik-Left Socialist Revolutionary (SR) coup (25-26 October 1917) and the dissolution of the All-Russian Constituent Assembly after its first meeting (5-6 January 1918), however, marked a halt in Russia's participation in global parliamentary developments, which institutionally encompassed, inter alia, Persia, the Ottoman Empire, and the Qing Empire (and the Republic of China) in the 1900s/1910s. Conceptually, it marked an end of the global parliamentary moment, as the Bolshevik-Left SR regime became the first practical

4 Although he did treat the Finnish Diet as a parliament by practices since 1863, see B. E. Nol'de, Ocherki Russkogo Gosudarstvennogo Prava [Essays on Russian State Law], Saint Petersburg: Pravda, 1911, pp. 10-11, 13-14, 49, 545.

5 K. Solov'ev, Samoderzhavie i Konstitutsiia: Politicheskaia Povsednevnost' v 1906-1917 Godakh [Autocracy and Constitution: The Political Everyday Life in 1906-1917], Moscow: Novoe literaturnoe obozrenie, 2019; A. Semyonov, “The Real and Live Ethnographic Map of Russia': The Russian Empire in the Mirror of the State Duma”, in: I. Gerasimov, J. Kusber, and A. Semyonov (eds.), Empire Speaks out: Languages of Rationalization and Self-Description in the Russian Empire, Leiden: Brill, 2009, pp. 191-228.

6 V. M. Gessen, Osnovy Konstitutsionnogo Prava [Foundations of Constitutional Law], Petrograd: Izd. iurid. kn. sklada Pravo, 1917, pp. 438-439. 
take on a non-parliamentary modernity. The subsequent development of the Soviet regime into a dictatorial one - which since 1936 was nevertheless accompanied by a nominal parliament (the Supreme Soviet) - conformed to the global anti-parliamentary developments. The 1920s and 1930s witnessed numerous authoritarian and totalitarian regimes across the world - in Italy, Germany, Spain, Portugal, Romania, Bulgaria, Yugoslavia, Greece, China, Mongolia, Thailand, the Dominican Republic, Guatemala, Nicaragua, Venezuela, Brazil, and elsewhere. Although some of them retained nominal parliamentary institutions, confirming in a way that political modernity required a parliament, they favoured consensus over dissensus, avoided any genuine public debates and political competition, and relied on party and personal governance. Some of these regimes fell during the Second World War, but new non-parliamentary regimes emerged in the 1940s and 1950s: these regimes included the new dependencies and the Cold War allies of the Soviet Union (Albania, Bulgaria, Czechoslovakia, Hungary, China, North Korea, and North Vietnam), the allies of the USA (including South Korea and South Vietnam), and neutral states (including Indonesia). Over the ensuing decades, the non-parliamentary approach to modernity has continued to thrive despite a new major wave of democratization in the late 1980s and early 1990s.

Between 1905 and 1917, however, the opinion that Russia needed a parliamentary regime comparable to or even more democratic than its Western counterparts was dominant in the country's intellectual circles, like in other Eurasian contexts. Although the Western system was largely perceived as universal, there was a critical reception of Western models rather than a simple "import”, together with suggestions within the discussions among Eurasian intellectuals that the Eurasian empires were not yet ready for such popular participation as in Western Europe and America. ${ }^{7}$ Focusing on the intellectual and political discourse surrounding the Duma, including academic works, pamphlets, and party programmes, the current chapter outlines the main positions on parliamentarism that accompanied Russia's imperial transformation and locates it in the global intellectual landscape.

The arguments in favour of parliamentarism were context-specific but still rooted in two major global developments: the attempts either to modernize empires or establish post-imperial nation-states. The discussions of parliamentarism hence foregrounded the subalternity of specific Eurasian empires, which were

7 Ch. Kurzman, Democracy Denied, 1905-1915: Intellectuals and the Fate of Democracy, Cambridge, MA: Harvard University Press, 2008; E. Moniz Bandeira, "China and the Political Upheavals in Russia, the Ottoman Empire, and Persia: Non-Western Influences on Constitutional Thinking in Late Imperial China, 1893-1911”, Transcultural Studies 8 (2017) 2, pp. 40-78. 
politically and conceptually marginalized in a Western-centred world, and specific social groups, which were disenfranchized within imperial hierarchies. In contemporary debates at the time, Russia was understood as both a "subaltern empire" that needed to boost its efficiency to be globally competitive and an "empire of subalterns" that needed a major reconfiguration or complete demolition of its inner hierarchies. ${ }^{8}$ Although the interpretations of subalternity and the suggestions on how to escape it differed greatly, a parliament as a globally circulating concept and the State Duma as its concrete institutional form became an assemblage point for imperial nationalism, a heterogeneous discourse, and a political programme on how the imperial society could improve the performance of the imperial state. ${ }^{9}$

\section{Parliamentary Universalism}

Over the nineteenth century, liberal and socialist intellectuals discussed the idea of introducing representative government in Russia. Together with the activities of underground and émigré intellectuals, the introduction of elected, albeit property-based, zemstvo (local) self-government in 1864 and its restriction in 1890 stimulated interest in constitutionalism, but it was not until the Revolution of 1905-1907 when the discussions became widespread - thanks to popular rallies, short-lived freedom of press, the formation of a legislative assembly, and the legalization of political parties. Although the first fundamental theoretical works on constitutionalism and parliamentarism by Russian authors were already published in the nineteenth century, ${ }^{10}$ during the Revolution of 1905-1907 the debates became especially intense, with a number of new works being published across the empire. Despite the official pressure on the public discussions, they continued during the "Years of Reaction" (1907-1917) and

8 I. Gerasimov, “The Great Imperial Revolution”, Ab Imperio 2 (2017), pp. 21-44; V. Morozov, Russia's Postcolonial Identity: A Subaltern Empire in a Eurocentric World, Basingstoke: Palgrave Macmillan, 2015, pp. 1, 40-41.

9 I. Gerasimov et al., “Do the 'Assemblage Points' Exist?”, Ab Imperio 1 (2014), pp. 16-21; Semyonov, "The Real and Live Ethnographic Map of Russia”, pp. 191-228; R. Tsiunchuk, "Peoples, Regions, and Electoral Politics: The State Dumas and the Constitution of New National Elites”, in: J. Burbank et al. (eds.), Russian Empire: Space, People, Power, 1700-1930, Bloomington, IN: Indiana University Press, 2007, pp. 366-397.

10 The dissertation of Boris Nikolaevich Chicherin was arguably the most influential work on parliamentarism by a Russian author before 1905, see B. N. Chicherin, O Narodnom Predstavitel'stve [On Popular Representation], Moscow: Tip. Gracheva i Kº 1866. 
loomed large during the "democratic" period of the second revolution, between March and October 1917.

The discussions concerning a parliament in Russia were deeply connected to international, predominantly European, scholarship. Russian legal scholars were acquainted with the works by contemporary Western scholars of constitutionalism and parliamentarism; these Western works were also translated and published in Russian, often with introductions by Russian scholars. The works of the liberal Heidelberg professor Georg Jellinek, who developed a dualistic approach to studying the state as both a social and legal phenomenon, circulated widely, and those of William Anson, Abbott Lawrence Lowell, and Julius Hatschek were familiar to Russian scholars as well. ${ }^{11}$ Although both Russian and Western authors relied on country-specific data and acknowledged differences between different European states, parliaments were part of the normative modern universalism for many of them. ${ }^{12}$ Jellinek, for instance, described a parliament as "the organized people" and the institution that enabled the people itself to become the primary body of government. ${ }^{13}$

In the introduction to Woodrow Wilson's The State, which in its Russian edition had the subtitle The Past and Present of Constitutional Establishments, Maksim Maksimovich Kovalevskii, a historian, a legal scholar, and a deputy of the First Duma and the State Council, stressed that participation of citizens in political power was the main feature of the modern constitutional state, with local self-government playing a pivotal role in its stability. Even though societal self-government developed in the West, according to Kovalevskii, the political past of Western Europe and Russia had similarities, which could act as a premise for its establishment in Russia. Together with Kovalevskii's conviction of the evolution of the state and humanity at large, this all contributed to his idea that the Russians had to learn from the achievements of the "Romano-Germanic" world, albeit not uncritically. ${ }^{14}$

11 K. N. Sokolov, Parlamentarizm: Opyt Pravovoi Teorii Parlamentskogo Stroia [Parliamentarism: A Legal Theory of the Parliamentary Regime], Saint Petersburg: Pechantnyi Trud, 1912, pp. vii, 6-7, 59, 379, 390.

12 E. Flanden, Politicheskie Uchrezhdeniia Sovremennoi Evropy: Angliia, Bel'giia [Political Institutions of Contemporary Europe: England, Belgium], Saint Petersburg: Izdanie V. I. Iakovenko, 1906, pp. ii.

13 G. Ellinek, Obshchee Uchenie o Gosudarstve [The General Theory of the State], ed. S. I. Gessen, 2nd edn, Saint Petersburg: N. K. Martynov, 1908, pp. 429-33.

14 M. M. Kovalevskii, "Predislovie k Russkomu Perevodu ["Introduction to the Russian Translation"]”, in: V. Vil'son, Gosudarstvo: Proshloe i Nastoiashchee Konstitutsionnykh Uchrezhdenii: S Prilozheniem Teksta Vazhneishikh Konstitutsii [The State: The Past and Present 
Sergei Andreevich Kotliarevskii, a historian, a legal scholar, and one of the founding members of the liberal Constitutional Democratic (KD) Party supported the argument of parallel development of Russia and the West toward the same goal. Reminding his readers that in Russia all "liberation traditions" were democratic, Kotliarevskii asserted that when it came to the reconfiguration of the state, "the democratic principle" was unquestioned. Hence the slogan of universal suffrage did not mimic the Western model but articulated the "genuine needs" of the Russian society and was, according to Kotliarevskii, in the state's interest. Although Kotliarevskii favoured "democratic parliamentarism", the notion of political evolution and Russia's inferiority compared to the West helped him justify the existence of the "Prussian regime" of a unanswerable cabinet as a transitional stage. Despite his scepticism of the Duma's "parliamentarism", he urged Russia's progressives to set parliamentarism - rather than radical republicanism - as their ultimate goal. ${ }^{15}$ In practical terms, this translated into the KD programme of constitutional monarchy, featuring a potent universally elected "popular representation" - the term usually used for a parliament. $^{16}$

The fundamental work Constitutional Law: The General Theory of the State (in its Russian edition) by Léon Duguit, a French legal scholar, which had an introduction by Pavel Ivanovich Novgorodtsev, himself a legal scholar and a KD deputy of the First Duma, offered a moderate interpretation of parliamentarism, suitable for the KDs. Duguit opposed the literal understanding of the separation of powers, which engendered conflict between different bodies claiming to represent the national will, and suggested the notion of cooperation of representative bodies with separate functions. According to Duguit, monarchy could not be considered representation in theory, but England's political practice justified the existence of constitutional monarchy, with old and new social forces cooperating in the interest of the country. Furthermore, according to Duguit, in large countries the dominance of a parliament under a republican regime could make it tyrannical. The takeaway was, however, not that monarchy was a

of Constitutional Establishments: With an Annex of the Texts of the Most Important Constitutions], Moscow: Izd. V. M. Sablina, 1905, pp. xxix, xxxiii-xxxv, xliii.

15 S. A. Kotliarevskii, "Problema Demokratizatsii Gosudarstva [1906] ["The Problem of State Democratization”], in: I. B. Borisov et al. (eds.), Politicheskie Instituty, Izbiratel'noe Pravo $i$ Protsess $v$ Trudakh Rossiiskikh Myslitelei XIX-XX Vekov [Political Institutions, Electoral Law and Process in the Works of Russian Thinkers of the Nineteenth-Twentieth Century], Moscow: Tsentral'naia izbiratel'naia komissiia Rossiiskoi Federatsii, 2008, pp. 568-570, 572.

16 G. F. Shershenevich, Programma Partii Narodnoi Svobody (Konstitutsionno-Demokraticheskoi) [The Programme of the Party of People's Freedom (Constitutional Democratic)], Moscow: Tipografiia G. Lissnera i D. Sobko, 1906, p. 6. 
superior form. Instead, Duguit favoured strong presidential rule and decentralization. The equality between the cabinet and the parliament - like in the USA and their ability to influence each other was an important check and a guarantee of freedom. For Duguit, under a parliamentary regime, the head of state appointed the cabinet, which was collectively and politically answerable to the parliament, but also had the right to summon, delay, and dissolve the parliament. Duguit was nevertheless convinced of the unidirectional political evolution, with universally elected parliaments to be eventually adopted by all civilized peoples. Duguit therefore had an optimistic prognosis for Russia, since "the reactionary movements" did not prevent it from joining the "great democratic current, inevitably carrying all civilized peoples away". Despite the dissolution of the First Duma on 8 July 1906, the tsar approved universal suffrage in Finland the day before. ${ }^{17}$

Konstantin Nikolaevich Sokolov, a legal scholar and a member of the KD Party, theorized that there was no contradiction between parliamentarism and monarchism in his Parlamentarizm: Opyt Pravovoi Teorii Parlamentskogo Stroia [Parliamentarism: A Legal Theory of the Parliamentary Regime]. For Sokolov, the cabinet, answerable to the majority of the lower house of the parliament, was the main feature of parliamentarism, yet the system also required a oneman head of state (monarch or president), bound by constitutional norms but not answerable to the parliament. In this respect, a parliamentary republic did not correspond to parliamentarism, as a neutral head of state was needed for representing the "eternal" interests of the state. Although he admitted that parliamentarism was not the summit of the whole democratic evolution, Sokolov celebrated parliamentarism as being capable of meeting the political needs of a country seeking a democratic regime but not desiring to give up monarchy. Notwithstanding, Sokolov repudiated the view that states could be divided into capable and incapable of parliamentary development, stressing the unidirectional political evolution. Appealing to the example of the German Empire where Chancellor Bernhard von Bülow had to resign due to a change in the ruling coalition in the parliament, who acted without any legal reasons to do so Sokolov highlighted the inevitable evolution of dual monarchies (in which the cabinet was not answerable to the parliament) into parliamentary ones. At the same time, parliamentarism could not simply be established through codification; it required a parliamentary tradition corresponding to "popular legal

17 L. Diugi, Konstitutsionnoe Pravo: Obshchaia Teoriia Gosudarstva [Constitutional Law: The General Theory of the State], Moscow: Tipografiia T-va I. D. Sytina, 1908, pp. 431, 438, 440-441, 450-452, 454, 456-458, 475, 491, 503-504, 506-507, 542-547, 549, 553-554, 560-561, 566-578. 
consciousness", a concept Sokolov borrowed from Lev Iosifovich Petrazhitskii's psychological theory of law. ${ }^{18}$

The KDs included parliamentarism, being understood as the answerability of the cabinet to the parliament's majority, into their programme in 1905. The other two largest opposition parties - the Party of Socialists Revolutionaries and the Russian Social Democratic (SD) Labour Party - supported the slogan of a democratic republic. The 1903 SD programme included a democratic republic - an "autocracy of the people" with the concentration of all state power in the hands of a legislative assembly - only as an immediate task, with a social revolution under the dictatorship of the proletariat being its ultimate goal. The SRs also included the slogan of the revolutionary dictatorship of the proletariat, if it became necessary, into their draft programme in 1905 but ultimately dropped it in favour of a democratic republic ruled by the people through their elected representatives and referendum. ${ }^{19}$ Polemicizing with the socialists, Pavel Nikolaevich Miliukov, a historian, a founding member of the KD Party, and a deputy of the Third and Fourth Duma, stressed in his speech at the KD's 1905 constituent congress that the party did not support the slogans of a democratic republic and the nationalization of the means of production, since some of its members did not support them at all, while others did not see them as part of "practical politics". Miliukov then drew a direct parallel between his party and Western intellectuals, claiming that it was especially close to "social reformists". 20

Although for socialists parliamentarism was not a goal but a means of achieving socialism, they did view the spread of the institution as a marker of global progress. Commenting on the Xinhai Revolution and the developments in the Republic of China in 1912, Vladimir Il'ich Lenin celebrated the awakening of the "four hundred million backward Asians" to political life and stressed the

18 Sokolov, Parlamentarizm: Opyt Pravovoi Teorii Parlamentskogo Stroia, pp. v-vi, 2, 7, 19, 60, 104, 122, 352-355, 378, 395-397, 403, 405-406, 408, 410-411, 414-416, 421-423, 425-430, 432.

19 Partiia Sotsialistov-Revoliutsionerov [Party of Socialists-Revolutionaries], Nasha Programma: Obshchedostupnoe Izlozhenie [Our Programme: A Commonly Accessible Version], Saint Petersburg: Partiia Sotsialistov-Revoliutsionerov, 1908, pp. 24-26; Programmy Russkikh Politicheskikh Partii [The Programmes of Russian Political Parties], Saint Petersburg: Izdanie V. Kharitonova, 1905, pp. 54-55, 64-65; Shershenevich, Programma Partii Narodnoi Svobody (Konstitutsionno-Demokraticheskoi), pp. 9-10.

20 P. N. Miliukov, “Vstupitel'naia Rech' Na Uchreditel'nom S'ezde K.-D. Partii, 14 Oktiabria 1905 Goda” [“Opening Speech at the Constituent Congress of the KD Party, 14 October 1905”], in God Bor'by: Publitsisticheskaia Khronika 1905-1906 [The Year of Struggle: A Publicist Chronicle of 1905-1906], Saint Petersburg: Tipografiia t-va “Obshchestvennaia pol'za, 1907, pp. 100-101. 
importance of the convocation of the Chinese parliament - "the first parliament in a former despotic country". ${ }^{21}$ Returning to the issue in 1913, Lenin called the Chinese parliament "the first parliament of the [a] great Asian country" and praised Sun Yat-sen's Nationalist Party (Guomindang) for bringing the broad masses of Chinese peasants into politics and calling it "a great factor of progress of Asia and progress of humanity".22

During the Revolution of 1917, the KDs amended their programme, calling for a "democratic parliamentary republic" instead of a constitutional monarchy. The executive branch was to be headed by a president to be elected by the parliament and to govern through the cabinet, which would be answerable to the parliament. ${ }^{23}$ In this respect, the party opted for a more radical parliamentary regime than either Duguit or Sokolov suggested for a country like Russia. In Osnovy Konstitutsionnogo Prava, Gessen also understood political answerability of the cabinet to the parliament as the main feature of parliamentarism but did not see the equality between the two bodies as necessary. On the contrary, the independence of the cabinet would, according to Gessen, lead to dual power. He also supported the strict separation of powers, which was best done in republics. At the same time, Gessen saw the readiness of particular countries for a republic as unequal. Until a monarch no longer was considered an embodiment of the state idea in the "consciousness of the popular masses", a republic was impossible and would be seen as anarchy. ${ }^{24}$

Gessen rejected, however, the notion of popular sovereignty. For him, the people were the source of legislative authority in a representative republic but were not seen as capable of exercising it due to the lack of a deliberate unity of wills. Legislative authority was exercised by the parliament on behalf of the people and in its interests, but the election of deputies was not a delegation of legislative competence since the people did not have it in the first place. A citizen was a voter, and not a lawmaker, who adopted legislation through his or her representatives. According to Gessen, the parliament received its competence from the constitution and not from the people, but the elections were still

21 V. I. Lenin, “Obnovlennyi Kitai” [1912] [“Renewed China”], Polnoe Sobranie Sochinenii [Collected Works], 5th edn, vol. 22, Moscow: Izdatel'stvo politicheskoi literatury, 1968, pp. 189-191.

22 V. I. Lenin, "Bor'ba Partii v Kitae" [1913] ["The Struggle of Parties in China"], Polnoe Sobranie Sochinenii, 5th edn, vol. 23, Moscow: Izdatel'stvo politicheskoi literatury, 1973, pp. 138-140.

23 Konstitutsionno-demokraticheskaia partiia [Constitutional Democratic Party], Programma Partii Narodnoi Svobody (K.-D.) [The Programme of the Party of People's Freedom (KD)], Odessa: Konstitutsionno-demokraticheskaia partiia, 1917, p. 3.

24 Gessen, Osnovy Konstitutsionnogo Prava, pp. 23, 32-34, 140-141, 417-419. 
needed for the will of the parliament to correspond to popular interests. Gessen concluded that popular representation implied the incapacity of the people. In his view, a parliament was not and could not be a cliché of the popular masses; it organized and created the general will, turning the anarchy of circulating opinions into one. ${ }^{25}$

Socialists did not share such a view on popular representation, with Mark Veniaminovich Vishniak, a legal scholar and a member of the SR Party, insisting that according to the idea of democracy (narodopravstvo), as initially formulated by Jean-Jacques Rousseau, only the people were the source of public opinion, that is to say of the will directed at the common good. A parliament, according to Vishniak, was only a secondary institution articulating but not creating popular will, which very much corresponded to Jellinek's interpretation of the people as the primary body and the parliament as the secondary body. ${ }^{26}$

\section{Right and Left Anti-Parliamentarisms}

The debates on parliamentarism featured many critical voices focusing on the deficiencies of the State Duma and other contemporary parliaments as well as the inadequacy of the parliamentary system as such. The issue of subalternity was prominent in the works of both radical left and far right intellectuals. The former focused on class subalternity and the failure of Western parliamentarism to address it, with the anarchists campaigning against the state as such. The criticism of the latter foregrounded Russia's self-sufficient greatness, endangered, inter alia, by parliamentary ideas and other aspects of Westernization, decrying the perceived violation of the interests of the ethnic Russians by political parties and non-Russians.

The idea of Russia's conceptual subalternity in a Western-centred world dates back to the Slavophiles and the Pochvenniks ("those calling to return to the soil") and the conservative elites, which facilitated the official state-centred Russian nationalism of the nineteenth century. The Revolution of 1905-1907 intensified the criticism of Russia's conceptual dependency on the West. Vasilii Vasil'evich Rozanov, a conservative philosopher, refused to admit that a constitution and a parliament were introduced in Russia, maintaining that the Duma

25 Gessen, Osnovy Konstitutsionnogo Prava, pp. 138-141.

26 M. V. Vishniak, Uchreditel'noe Sobranie i Proportsional'nye Vybory [The Constituent Assembly and Proportional Elections], Petrograd: Tip. Ts. K. Partii Sotsialistov-Revoliutsionerov, 1917, p. 16; Ellinek, Obshchee Uchenie o Gosudarstve, pp. 429-433. 
was a product of Russian history - produced by the Russian soul, enthusiasm, patience, and work - and not a "foreign novelty". Although Rozanov admitted that the Russian people also moved to liberation like elsewhere, this movement was parallel to those of the others. For Rozanov it did not have the same direction. The Duma did not mimic Western institutions and was not a place for representing difference, and Rozanov called for unity amongst Russia's political groups, directed at mitigating the splits in the Russian society. ${ }^{27}$

Aleksandr Petrovich Liprandi, a right-wing monarchist political writer, cited the experience of Western empires when rejecting Russia's need for parliamentarism. Countering the argument that autocracy resulted in the defeat in the Russo-Japanese War, he asserted that the initial failures of the British in the Boer Wars (1880-1881 and 1899-1902) and the loss of the Spanish-American War (1898) by Spain demonstrated that a parliament did not boost the state's military efficiency (albeit he did not comment on the USA having a parliament of its own). Furthermore, Liprandi claimed that parliamentarism was the reason why empires failed, pointing to Spain and Sweden, which lost their great power status after political liberalization, and to the crisis in Austro-Hungary. According to Liprandi, the German Empire, by contrast, came to prominence due to the efforts of Otto von Bismarck and Wilhelm II as well as minimal parliamentary influence. Liprandi concluded that Russia was self-reliant. Although he did see Russia as subaltern and in need of catching up with the West, in his opinion it lagged behind due to being under the Mongol yoke from the thirteenth to the fifteenth century. ${ }^{28}$

Other right-wing writers dismissed the role of parliamentarism in the global leadership of the British Empire. Vladimir Ivanovich Ger'e, a historian, an appointed member of the State Council, and a member of the centre-right Union of October 17 (Octobrists), acknowledged England's political mechanism. Yet, in his opinion, this mechanism was based on the country's aristocratic regime and deteriorated together with it. Parliamentarism, according to Ger'e, meant transferring state power to parties. Given that their members were "slaves to party discipline" rather than citizens, parliaments turned into "fairs". Ger'e stressed that a popular representation, consisting of many sporadic parties and

27 V. V. Rozanov, "Gosudar' i Gosudarstvennaia Duma” [1906] [“The Tsar and the State Duma”], in: I. B. Borisov et al. (eds.), Politicheskie Instituty, Izbiratel'noe Pravo i Protsess $v$ Trudakh Rossiiskikh Myslitelei XIX-XX Vekov [Political Institutions, Electoral Law and Process in the Works of Russian Thinkers of the Nineteenth-Twentieth Century], Moscow: Tsentral'naia izbiratel'naia komissiia Rossiiskoi Federatsii, 2008, pp. 607-608.

28 A. P. Liprandi, Nuzhen Li Rossii Parlamentarizm? [Does Russia Need Parliamentarism?], Kharkov: Mirnyi Trud, 1910, pp. 9-10, 18, 35-36, 60. 
groups, could not rule "a great empire" due to their mutual hate and lack of experience and traditions. ${ }^{29}$

Vladislav Frantsevich Zalesskii, a legal scholar, an economist, and a rightwing Black Hundred activist in the Kazan Province, and Liprandi explicated partisanship, engendered in parliamentarism, in their criticisms. They heavily relied on contemporary academic and public discussions of parliamentarism in Russia and in the West, citing Josef Schöffel, Ettore Lombardo Pellegrino, Alfred Offermann, Karl Walcker, and other authors. According to Zalesskii, contemporary deputies represented partisan rather than state interests at the expense of common good. He called parliamentary rule many-headed tyranny and tyranny of the majority, dismissing both the very principle of majority rule as erroneous and pointing that a minority claiming to be the majority could impose its will through parliamentarism, depending on electoral constellations. Sharing such views, Liprandi added that partisanship was also detrimental for deliberation, as everything was decided within factions. ${ }^{30}$

For the far right, the threat to the "greatness" of the state was intertwined with the supposed threats to the ethnic Russians. Rozanov's aspiration for unity in the State Duma was shattered by the oppositional majorities of the first two Dumas, which triggered their dissolution. Anticipating the convocation of the Third Duma, based on the limited electoral law, Rozanov expected the new Duma to finally become one of the "state" and not one of the "society", thereby rejecting the liberal notion of societal self-organization. Rozanov expressed hope that the Duma would be a "national Russian" representation and personally attacked the Armenian Arshak Gerasimovich Zurabov and the Georgian Isidor Ivanovich Ramishvili, the SD deputies in the Second and First Duma respectively. What progressives and non-Russian nationalists saw as the ethnic non-Russians finally gaining a voice through the Duma, ${ }^{31}$ Rozanov saw as a clear indication that the Russian state and the ethnic Russians (who in practice made up some 44.3 per cent of the imperial population in terms of language but legally also included the 17.8 per cent speaking Ukrainian and 4.7 per cent speaking Belarusian, thereby becoming a majority $)^{32}$ could become subaltern;

29 V. I. Ger'e, “O Konstitutsii i Parlamentarizme v Rossii” [1906] [“On the Constitution and Parliamentarism in Russia"], in: Borisov et al. (eds.), Politicheskie Instituty, pp. 595-597.

30 Liprandi, Nuzhen Li Rossii Parlamentarizm?, pp. 13-14, 18-19; V. F. Zalesskii, Parlamentarizm i Ego Otsenka Na Zapade [Parliamentarism and Its Evaluation in the West], Moscow: Russkaia pechatnia, 1909, pp. 10-13, 15-17.

31 Semyonov, “"The Real and Live Ethnographic Map of Russia”".

32 Institut demografii Natsional'nogo issledovatel'skogo universiteta Vysshaia shkola ekonomiki [The Institute of Demographics of the National Research University Higher School of 
he claimed that the "grey-haired old Rus", embodied by the people of "serious positions and professions", had to listen to the "nonsense" of the deputies from the Caucasus. ${ }^{33}$ Ger'e also specifically attacked the SDs, calling them "a party of the liberation of Caucasus from Russia, rather than the liberation of Russia from capitalists". ${ }^{34}$

Similar to Rozanov, Zalesskii supported the state in the dichotomy between state and society, which was crucial for contemporary debates, and claimed that parliamentarism contradicted the idea of the state by allowing the society to take it over. The society, for Zalesskii, was a people divided by access to moral and material goods and a means for achieving selfish individual interests. It could not overcome the divisions by itself, and only the state, as a force above the society, could subordinate all individual interests to one goal - the goal of the good for the whole people. Parliamentarism, which allowed groups to form based on their own interests, hence undermined the capacity of the state to do so. Agreeing with Ger'e's opinion that England's experience was unique, Zalesskii dismissed the notion of parliamentarism's natural spread through the civilized world over the nineteenth century as blind copying of the English system. ${ }^{35}$ In a similar manner, Liprandi asserted that institutions could not simply be copied due to the ubiquitous, different conditions. Russia, according to Liprandi, was incomparable to England, and constitutionalism contradicted the character and the worldview of the Russian people. ${ }^{36}$

Citing the experience of the Habsburg Empire, Zalesskii claimed that parliamentarism was specifically dangerous for multiethnic states, since deputies did not represent the whole people but only their national groups. ${ }^{37}$ Liprandi supported this line of argumentation, claiming that in multiethnic states like AustroHungary and Russia the combination of national and party struggle was against the very idea of empire, threatening to fragment the state. Like other rightists, he combined chauvinism with conspiracy theories, which saw European majorities as subalterns, claiming that the French people were victimized by the "Free Masons, Jews, and socialists", who pretended to be popular representatives,

Economics], “Pervaia Vseobshchaia Perepis’ Naseleniia Rossiiskoi Imperii 1897 g.” [“The First General Census of the Russian Empire of 1897"], http://demoscope.ru/weekly/ssp/census. php?cy=0 (accessed 1 December 2015).

33 V. V. Rozanov, "Chastnyi i Obshchestvennyi Interes v Gosudarstvennoi Dume" [1907] ["Private and Public Interest in the State Duma"], in: Borisov et al. (ed.) Politicheskie Instituty, pp. 616-617.

34 Ger'e, “O Konstitutsii i Parlamentarizme v Rossii [1906]”, pp. 595-597.

35 Zalesskii, Parlamentarizm i Ego Otsenka Na Zapade, pp. 5-10, 37-38.

36 Liprandi, Nuzhen Li Rossii Parlamentarizm?, p. 66.

37 Zalesskii, Parlamentarizm i Ego Otsenka Na Zapade, pp. 39-40. 
during the separation of the church from the state. In a similar manner, "Masons, Jews, and aliens [inorodtsy, the domestic 'foreigners']"38 supposedly invented the Revolution of 1905-1907. Liprandi, nevertheless, decried the lack of proportional representation of Slavic population in the Habsburg Empire and claimed that the Slavic majority in Hungary was victimized by the Hungarians. ${ }^{39}$

Despite their rejection of societal self-organization, rightists also participated in mass politics. Speaking at the Third All-Russian Congress of the Russian People (Kiev, 2-7 October 1906), Zalesskii maintained that Russia had to get rid of parliamentarism as the "mediastinum" that prevented unity between the tsar and the people. Presenting constitutionalism and minority rights as a Western conspiracy, the Russian National Union of Archangel Michael, a radical right-wing monarchist party, went further and cautioned the representatives of the Inter-Parliamentary Union from visiting Russia in 1910. Accusing them of pushing Russian state life onto the "constitutional course" and pressuring Russia in its relations with the ostensibly oppressed Finland, the organization called for monarchist and nationalist organizations to protest, suggesting that if during such protests the visitors were harmed, then they only had themselves to blame. ${ }^{40}$

The First World War and the formation of the Progressive Bloc in the Duma and the State Council in 1915 - a liberal and moderate nationalist parliamentary majority that demanded liberal reforms, including a "cabinet of popular trust" stimulated anti-parliamentarism of the far right. In October 1915, the Union of the Russian People, the largest right-wing monarchist organization, issued a proclamation claiming that the "inner enemies" of the motherland - "constitutionalists, parliamentarians, revolutionaries, and especially Germans and Jews" used the temporary problems with military supplies to deceive the Russian people. According to the proclamation, demanding that the tsar appointed ministers from among them, the "Judeo-Masons" sought to seize the power and limit the rights of the tsar under the guise of patriotism. It once again rejected the argument that autocracy was responsible for the failures regarding war and pointed to the defeat of Belgium and the failures of France, which had answerable cabinets, as well as to the strength of Germany, which did not have one. ${ }^{41}$ Speaking at the All-Russian Monarchist Conference (Nizhny Novgorod, 26-29

38 This was a legal social estate including many representatives of ethnic non-Russians.

39 Liprandi, Nuzhen Li Rossii Parlamentarizm?, pp. 11, 66-67.

40 Iu. I. Kir'ianov (ed.), Pravye Partii, 1905-1917 gg.: Dokumenty i Materialy [Right-Wing Parties, 1905-1917: Documents and Materials], vol. 1: 1905-1910 gg., Moscow: ROSSPEN, 1998, pp. 220, 570 .

41 Ibid., vol. 2: 1911-1917 gg., Moscow: ROSSPEN, 1998, pp. 474-475. 
November 1915), Nikolai Evgen'evich Markov, a deputy of the Third and Fourth Duma and one of the leaders of the Union of the Russian People, added that the Russian SDs were misguided and spiritually enslaved by the "Jew-German" Karl Marx. $^{42}$

Right-wing writers backed their anti-parliamentary views with numerous examples of how parliamentarism failed, or supposedly failed, in the West. Zalesskii offered sporadic cases of corruption and inefficient spending in Europe and the USA as a proof of parliamentarism's inefficiency. Liprandi asserted that in free countries corruption was freer, as corrupted administrators were protected by their parties, which would not risk losing an election by exposing their own members. Both Zalesskii and Liprandi maintained that the West itself was disenchanted with parliamentarism. Citing Schöffel, Liprandi claimed that parliamentarism resulted in the fall of popular morality through, for instance, the conduct of electoral campaigns, falsification of elections, as well as threats to and bribery of the voters. Citing Friedrich Nietzsche and other European intellectuals, he called liberalism the victory of the "herd" principle, as it brought people to one poor standard, and suggested that Russia was to play a special role in the future, given the spiritual decay of Western Europe. When discussing the corruption of parliaments in the West, Liprandi used the arguments of socialist intellectuals, claiming that, for example, in Sweden and the USA the parliaments were owned by capitalists. Furthermore, he even cited Petr Alekseevich Kropotkin, a leading anarchist writer, when criticizing the corruption of Western parliaments and the lack of expertise among the deputies. ${ }^{43}$

Indeed, for anarchists, parliaments were unacceptable in any form. In the Russian translation of Words of a Rebel, which was first published in French in 1885, Kropotkin formulated his stance on parliamentarism. According to Kropotkin, representative regimes were not a source of freedom but a mere acknowledgement of the rights that the people conquered through rebellions. As institutions, parliaments remained representatives of the propertied class. Besides, they would always remain an institution of subordination of the majority to a ruling minority, and hence their membership was irrelevant. ${ }^{44}$ Kropotkin's position was taken up by other Russian anarchists. A 1906 proclamation of the Moscow AnarchistsCommunists, for instance, called the working people to boycott not only the "tsarist" State Duma but also a possible "revolutionary" constituent assembly. The

42 Ibid., pp. 497-498.

43 Liprandi, Nuzhen Li Rossii Parlamentarizm?, pp. 1-4, 5, 8, 11-12, 31-35, 57-59, 68-70; Zalesskii, Parlamentarizm i Ego Otsenka Na Zapade, pp. 1-5, 22-23.

44 P. A. Kropotkin, Rechi Buntovshchika [1885] [Words of a Rebel], Saint Petersburg: Redaktor-izdatel' Valerii Brodskii, 1906, pp. 89, 101. 
toilers were to "lose any faith in their liberation through the parliament (from above) and believe only in the might of their organizations". According to the proclamation, when the moment was ripe, the toilers were to liberate themselves by seizing the means of production and organizing communal economy. ${ }^{45}$

Kropotkin himself reaffirmed the radical anti-parliamentary view at the congress of Anarchists-Communists (London, 17-18 September 1906). He rejected the idea of dividing the struggle into two steps - a political coup and economic reforms ostensibly to be implemented by a Russian parliament. The struggle against autocracy and capital was to be simultaneous. Any parliament was a deal between the parties of the past and those of the future and hence would never introduce revolutionary measures. The most revolutionary parliament would only be able to legalize what the people would have already achieved by then. Presenting Russia's uniqueness from a different angle, Kropotkin maintained that the Russian people had a historic chance to take power into their own hands and surpass the stages that the West went through. According to Kropotkin, the workers were to self-organize into unions to fight against capital and to rule themselves later and avoid parliamentary gradualism. ${ }^{46}$

On the far right, the notion of class subalternity was combined with that of the Russian people, producing right-wing populism. The Union of the Russian People explicated the differences between sobornost' (roughly meaning spiritual community) and Western parliamentarism and constitutionalism from an anti-Semitic and conspiratorial standpoint in their programme documents in 1912. Parliamentarism ostensibly served God, the state, and popular needs in word only, whereas in truth it served "Mammon", revolution, and "the monstrous cosmopolitan Hydra, sucking the wealth from the Russian people into the international Jewish banks, enslaving the holy Russian land and its people to the global union of the Free Masons and the 'intelligentsia' leading it". Sobornost', according to the organization, was led by the tsars, embodied in the Russian Assemblies of the Land (Zemskie Sobory), ${ }^{47}$ and fed by the unity and mutuality of all estates. European parliaments, by contrast, emerged out of enmity towards supreme authority and the desire to take this authority for themselves.

45 V. V. Kriven'kii (ed.), Anarkhisty: Dokumenty i Materialy 1883-1935 gg. [Anarchists: Documents and Materials of 1883-1935], vol. 1: 1883-1916 gg, Moscow: ROSSPEN, 1998, pp. 202-203.

46 Ibid., pp. 230-234, 241-242.

47 This term uniting different early modern gatherings under one concept was a nineteenthcentury invention, see N. Shields Kollmann, The Russian Empire, 1450-1801, Oxford: Oxford University Press, 2017, p. 137. 
Every member of parliament always defended individual or group profit and the interests of the capital, deceiving the popular masses. ${ }^{48}$

Nestor Nikolaevich Tikhanovich-Savitskii, a businessman, a regional leader of the Union of the Russian People, and later the founding chairman of the Astrakhan People's Monarchist Party, combined far right attitudes with leftist economic slogans. Criticizing Russia's unionist movement during the First World War - the broad self-organization into zemstvo, municipal, cooperative, industrial, and other groups as both a means of social participation in the war effort and a substitute for the inefficient Duma - and calling for its suppression in his appeal to Nicholas II in March 1916, Tikhanovich-Savitskii suggested to dissolve and abolish the Duma for spreading panic among the population and calling for a coup d'état at a time of war. Dismissing the "dirt of European parliamentarism" as incompatible with Russia's future, he called it a servant of "capitalists and bourgeois intelligentsia”, enslaving the people. Consequently, Russia's future was in the "Russian autocracy", relying on the "popular masses”. In the Osnovnye Polozheniia Narodnykh Monarkhicheskikh Soiuzov [Points on People's Monarchist Unions], which he developed by May 1916, Tikhanovich-Savitskii made even greater use of socialist discourse. Claiming that "the rich needed the constitution and the parliament", he explained that it was "the banks, syndicates, [and] rich industrialists", supported by the "bourgeois classes of the society", that wanted to limit the authority of the tsar through the establishment of an answerable cabinet. The supposed goal of the rich was also discussed from a socialist standpoint. The document claimed that such a cabinet was to adopt such laws that would support their interests at the expense of the interests of the "middle and lower classes of the toiling population". 49

It was, however, neither the rightists nor the anarchists who led the antiparliamentary movement during the Revolution of 1917. The SD slogan of the "autocracy of the people" took a non-parliamentary shape in April 1917, after Lenin returned to Russia and consolidated his leadership among the Bolsheviks. The latter's conference adopted a resolution calling for the transfer of authority to the soviets (councils) as bodies of direct workers' and peasants' rule during the second phase of the revolution. Even though the resolution did not fully reject the institution of parliament, suggesting that state power could also be transferred to the Constituent Assembly or local self-government bodies, it marked the formal departure of the Bolsheviks from the 1903 SD programme. The conference resolved to amend the party programme, replacing the demand for a

48 Kir'ianov (ed.), Pravye Partii, vol. 2, pp. 212-213.

49 Ibid., pp. 546, 553. 
"bourgeois-parliamentary republic" with the demand for a "democratic proletarian-peasant republic", that is to say "a state without police, army, and privileged bureaucracy". 50

Lenin's ideas during the period were more radical than the resolutions of the April 1917 conference and reflected the popularity of anarchist slogans, especially in the Russian army. He practically took over the anarchist idea of Russia being capable of surpassing the stages of Western development and embodying an alternative modernity. As summarized in the Bolshevik newspaper Pravda (Truth), for Lenin the soviets of workers' and soldiers' deputies were a "new unique organization of state power". Such organizations, according to Lenin, were radically different from all previously existing ones and were "in no way suitable for the establishment of bourgeois institutions, for the establishment of a bourgeois parliamentary republic". With the formation of the Petrograd Soviet of Workers' and Soldiers' Deputies and local soviets, the power was already in the hands of organized armed people. At the same time, Lenin claimed that a socialist revolution, which he anticipated in the West, was not to be immediately expected in Russia, although Russia had entered the transition to it. $^{51}$

\section{Competing Designs}

Moderate nationalists and socialists, together with liberals, still viewed a parliament as a possible means of achieving their goals. The theoretical approaches to parliamentarism, the notions of subalternity, the experience of the State Duma and foreign parliaments, and the confluences of party and broader revolutionary politics framed the debates on the specific forms a Russian parliament could take. Parties began to design a future parliament during the Revolution of 1905-1907, but it was the fall of the monarchy in 1917 and the anticipation of the All-Russian Constituent Assembly that made the debates especially intense.

50 Sed'maia (Aprel'skaia) Vserossiiskaia Konferentsiia RSDRP (Bol'shevikov); Petrogradskaia Obshchegorodskaia Konferentsiia RSDRP (Bol'shevikov): Aprel' 1917 Goda: Protokoly [The Seventh (April) All-Russian Conference of the RSDLP (Bolsheviks); The Petrograd City Conference of the RSDLP (Bolsheviks): April 1917: Minutes], Moscow: Gosudarstvennoe izdatel'stvo politicheskoi literatury, 1958, pp. 258-260.

51 "Newspaper Report on the Seventh (April) All-Russian Conference of the RSDLP(b)", Polnoe Sobranie Sochinenii, 5th edn, vol. 31, Moscow: Izdatel'stvo politicheskoi literatury, 1969, pp. 359-360. 
Iulii Osipovich Martov, who after the split of the SDs in 1903 was one of the Menshevik leaders, stressed in a popular booklet that the struggle between different parties during the elections, in the parliament, and in the press was the same class struggle. Yet he did not call for boycotting parliaments as such and urged voters to determine what class interests a party represented. ${ }^{52}$ After the boycott of the elections to the First Duma by socialist parties brought little result, many SDs agreed to use the Duma as a rostrum for revolutionary propaganda. Defending such a position, the Menshevik Fedor Il'ich Dan stressed the need to direct popular attention at specific issues through the elections under party programmes and the discussions in the Duma, disregarding its nature as a non-parliament and contributing to the future uprising. ${ }^{53}$

During the Years of Reaction, some SDs also considered broader participation in the Duma. Speaking at the Vienna Conference of the SDs, which united the Mensheviks and other non-Bolshevik factions in 1912, Mikhail Isaakovich Liber, a Menshevik and a so-called Liquidator (seeking to confine the SD activities to legal forms), maintained that the slogan of a democratic republic did not contradict the slogan of a potent Duma. The SDs therefore could also facilitate the popular movement through parliamentary activity. Moderate SDs disagreed with Lenin, who claimed earlier that year that the period of peaceful parliamentarism in Western Europe was coming to an end and reiterated the slogan of the dictatorship of proletariat and peasantry in Russia, although the forms of the latter were yet to be set. ${ }^{54}$

Moderate liberal, socialist, and conservative discourses were not monolithic and suggested different solutions to the issue of class subalternity. For Gessen, it lay in parliamentarism. Although, according Osnovy Konstitutsionnogo Prava, there were many deputies in contemporary parliaments who represented class interests, the character of contemporary elections resulted in the election of one deputy by different social classes and hence held narrow class politics in check. ${ }^{55}$ Ger'e viewed the solution in "constitutional" rather than "parliamentary" monarchy. Unlike the latter, it represented not the rule of parties but the rule of the government above them. Accordingly, constitutional monarchy kept the benefits of monarchist rule, such as the unity of will in the state. Because of

52 L. Martov, Politicheskie Partii v Rossii [Political Parties in Russia], Saint Petersburg: Novyi mir, 1906, pp. 29-31.

53 S. V. Tiutiukin (ed.), Men'sheviki: Dokumenty i Materialy, 1903-Fevral' 1917 gg. [The Mensheviks: Documents and Materials, 1903-February 1917], Moscow: ROSSPEN, 1996, p. 182. 54 Iu. N. Amiantov (ed.), Konferentsii RSDRP 1912 Goda: Dokumenty i Materialy [Conferences of the RSDLP of 1912: Documents and Materials], Moscow: ROSSPEN, 2008, pp. 569-570, 809.

55 Gessen, Osnovy Konstitutsionnogo Prava, p. 193. 
being independent from classes and parties, monarchy could mitigate the differentiation between them and observe the general interest - that being the interest of the state. ${ }^{56}$

Whereas the far right also boycotted the elections of the First Duma and occasionally obstructed its activities later, some right-wing intellectuals suggested using it as a proper institution. Mikhail Osipovich Men'shikov, a political writer and a founding member of the moderate right All-Russian National Union, acknowledged the benefits of political modernization for Japan. According to Men'shikov, in modern times it was impossible to be a great power without the moral participation of the people who would elect their best people. Men'shikov claimed, however, that one could never vote for the "criminal parties", implying the socialists, and those aliens who were the "enemies" of Russia, meaning those minority groups that had their own caucuses in the Duma - the Jews, Poles, Lithuanians, Tatars, and others. The elections were therefore supposed to boost the resistance of the ethnic Russians to the "alien pressure", which he compared to a war with foreigners. ${ }^{57}$

Unlike the SDs, the SRs, and socialist nationalist parties, which declared the need for universal (for both men and women) suffrage, the KDs and other liberal groups did not immediately support women's suffrage. Initially, zemstvo liberals backed universal male suffrage, whereas the first programme of the KD Party noted that a minority within the party, which was against female suffrage, was not bound by the programme's provision on universal suffrage. ${ }^{58}$ Since 1906, however, the KDs formally supported women's suffrage. In order to make the future republic democratic, the SRs suggested not only the universal right to vote but also broad participation of the population in legislation through referendums and the right to initiate legislation for groups of people. ${ }^{59}$

Socialists overwhelmingly supported proportional representation through voting by lists. The SR Dmitrii Aleksandrovich Magerovskii explained that only the proportional system ensured that a parliament was "a mirror of the country" by granting parties the number of seats that corresponded to their

56 Ger’e, “O Konstitutsii i Parlamentarizme v Rossii” [1906], pp. 589-591.

57 M. O. Men'shikov, "Kogo Vybirat' v Parlament" [1912] ["Who Should be Elected to the Parliament”], in: Borisov et al. (eds.), Politicheskie Instituty, pp. 688-693.

58 Partiia Sotsialistov-Revoliutsionerov, Nasha Programma: Obshchedostupnoe Izlozhenie, pp. 24-25; Programmy Russkikh Politicheskikh Partii, pp. 26, 43, 50, 55; Shershenevich, Programma Partii Narodnoi Svobody (Konstitutsionno-Demokraticheskoi), p. 8.

59 D. A. Magerovskii, Uchreditel'noe Sobranie i Ego Zadachi [The Constituent Assembly and Its Objectives], Moscow: Izdatel'stvo Burevestnik, 1917, pp. 20, 22. 
influence in the country. ${ }^{60}$ The KD programme did not demand proportional elections. Gessen rejected their necessity, arguing that since the parliament could not be a "mechanical cliché" of the masses, then the only condition was that the majority in the parliament reflected the majority in the country. According to Gessen, the proportional system represented only formally organized groups. ${ }^{61}$ Vasilii Vasil'evich Vodovozov, a moderate socialist educator and a legal scholar, openly supported a majoritarian system for Russia, claiming that the country was too large, that the proportional system would increase the fragmentation of political parties, and that it did not suit Russia's regional and ethnic diversity, as deputies elected through party lists would not be connected to particular localities and ethnic groups. ${ }^{62}$

The issue of representing minority, regional, and local interests made parliamentary designs dependent on the different approaches to decentralization, which between 1905 and 1917 were of utter importance for the SRs, KDs, and especially minority nationalist and regionalist groups. ${ }^{63}$ Zemstvo liberals suggested forming the State Duma with two chambers: the Chamber of Popular Representatives and the Zemstvo Chamber. Whereas the former was to be elected directly, the latter was to be formed by provincial zemstvo assemblies and municipal dumas of large cities. The KDs allowed for pluralism of opinions on the matter, with the option of the second chamber of self-government bodies in place. ${ }^{64}$ Kotliarevskii defended the idea of such a chamber and bicameralism in general, maintaining that a unicameral parliament would focus on narrow class interests and threaten with excessive centralization. Accompanied by local and regional decentralization, based on potent universally elected local self-government, the second chamber would serve as a safeguard against radicalism and embody democratic decentralization. ${ }^{65}$

Duguit offered a different approach to forming the second chamber. Suggesting that a nation was made up of both individuals and groups based on

60 Magerovskii, Uchreditel'noe Sobranie i Ego Zadachi, pp. 20, 22.

61 Gessen, Osnovy Konstitutsionnogo Prava, pp. 290-291, 308, 311, 314, 317-318, 322.

62 V. V. Vodovozov, Kakaia Sistema Dolzhna Byt' Priniata Dlia Izbraniia Uchreditel'nogo Sobraniia [What System Should Be Adopted for the Election of the Constituent Assembly], Petrograd: Zemlia i trud, 1917, pp. 11, 29-30.

63 I. Sablin and A. Semyonov, "Autonomy and Decentralization in the Global Imperial Crisis: The Russian Empire and the Soviet Union in 1905-1924”, Modern Intellectual History, https:// doi.org/10.1017/S1479244318000252 (accessed 18 June 2018).

64 Konstitutsionno-demokraticheskaia partiia, Programma Partii Narodnoi Svobody (K.-D.), p. 3; Programmy Russkikh Politicheskikh Partii, pp. 26, 43.

65 S. A. Kotliarevskii, "Predposylki Demokratii” [1905] [“Prerequisites of Democracy”], in: Borisov et al. (eds.), Politicheskie Instituty, pp. 559-560, 572-573. 
common interests and labour, he put forward the idea of the second chamber elected by professional groups, such as large industrial and art groups. ${ }^{66}$ During the Revolution of 1917, some socialists and liberals in fact viewed the soviets as "legislative chambers of deputies" and the Petrograd Soviet as "a surrogate people’s Duma”, which replaced the State Council in a two-house parliament of new Russia. ${ }^{67}$

The KD Party did not adopt a single position on the number of chambers by August 1917, postponing the resolution of the issue. Fedor Fedorovich Kokoshkin, a legal scholar and a deputy of the First Duma, supported the benefits of the second chamber for safeguarding local interests but suggested to wait until the forms of decentralization were decided upon. ${ }^{68}$ Gessen opposed the idea of a chamber of self-governments, insisting that local and minority interests would be ensured by broad self-government on site, and of a chamber of professional groups, since important collective interests often were not organized. ${ }^{69}$

Socialists, including those coming from the imperial peripheries, also overwhelmingly opposed the second chamber. The SDs had already specified unicameral parliamentarism in their programme in $1903 .^{70}$ The Armenian SD Bogdan Mirzadzanovich Knuniants maintained that even elected second chambers, such as the Senate in France, continued to represent the interests of the propertied classes and would hence slow down the legislation in favour of the toiling people. $^{71}$

Although most of the SRs supported unicameralism, there were voices in favour of bicameralism within the party, and the issue did not make it into their first programme. Speaking at the first SR congress (Imatra, 29 December 1905-4 January 1906), Viktor Mikhailovich Chernov, one of the party's leaders, suggested

66 Diugi, Konstitutsionnoe Pravo: Obshchaia Teoriia Gosudarstva, pp. 530-534.

67 I. Sablin, The Rise and Fall of Russia's Far Eastern Republic, 1905-1922: Nationalisms, Imperialisms, and Regionalisms in and after the Russian Empire, London: Routledge, 2018, p. 88 .

68 D. B. Pavlov (ed.), Protokoly Tsentral'nogo Komiteta i Zagranichnykh Grupp KonstitutsionnoDemokraticheskoi Partii, 1905-Seredina 1930-kh gg. [The Minutes of the Central Committee and Foreign Groups of the Constitutional Democratic Party, 1905-the middle of the 1930s], vol. 3: Protokoly Tsentral'nogo Komiteta konstitutsionno-demokraticheskoi partii, 1915-1920 gg. [The Minutes of the Central Committee of the Constitutional Democratic Party], Moscow: ROSSPEN, 1998, pp. 396-401.

69 Gessen, Osnovy Konstitutsionnogo Prava, pp. 356-358, 360-365.

70 Programmy Russkikh Politicheskikh Partii, p. 55.

71 B. Radin [B. M. Knuniants], Kakoe Izbiratel'noe Pravo Nuzhno Rabochemu Klassu [Which Electoral Law Does the Working Class Need], Saint Petersburg: Trud, 1906, p. 15. 
that a non-privileged second chamber representing the country's autonomous parts was possible in a federative system. ${ }^{72}$ Others, however, insisted that the autonomy of regions and minorities - to be realized through their own universally elected parliaments, which was put forward by the SRs and socialist nationalist parties - was sufficient. Speaking at the party's third congress (Moscow, 25 May 1917-4 June 1917), Vishniak advocated unicameralism, claiming that regional legislation, referendums, and the right to initiate legislation were sufficient. ${ }^{73}$

In the Labour People's Socialist Party, which was a successor of the moderate socialist Labour faction in the State Duma, there was also no single opinion on the matter, with some suggesting in the summer of 1917 a federal court instead of the second chamber. ${ }^{74}$ The Mensheviks retained a pluralism of opinions until the convocation of the All-Russian Constituent Assembly, with some in their faction tolerating the creation of a possible federal chamber. The party, however, refrained from initiating the discussion of autonomy and hence a possible federal parliament in the assembly. ${ }^{75}$

On 20 October 1917, the KD legal scholars Aleksandr Mikhailovich Kulisher and Boris Evgen'evich Shatskii presented a summary of approaches to the number of chambers to the Special Committee for Drafting the Fundamental Laws under the Provisional Government, which was chaired by Gessen and included Vishniak, Vodovozov, Kotliarevskii, and other liberal, socialist, and nonpartisan moderates. In their opinion, a possible second chamber could include both the representatives of autonomous territories and local self-government bodies and the representatives of the most important "organized social and cultural forces of the country", such as representatives of trade and industry,

72 N. D. Erofeev (ed.), Partiia Sotsialistov-Revoliutsionerov: Dokumenty i Materialy, 1900-1925 gg. [The Party of Socialists-Revolutionaries: Documents and Materials], vol. 1: 1900-1907 gg., Moscow: ROSSPEN, 1996, p. 405.

73 N. D. Erofeev (ed.), Partiia Sotsialistov-Revoliutsionerov: Dokumenty i Materialy, 1900-1925 gg., vol. 3, Part 1: Fevral'-oktiabr' 1917, Moscow: ROSSPEN, 1996, pp. 418-419.

74 A. V. Sypchenko and K. N. Morozov (eds.), Trudovaia Narodno-Sotsialisticheskaia Partiia: Dokumenty i Materialy [The Labour People's Socialist Party: Documents and Materials], Moscow: ROSSPEN, 2003, pp. 242, 244-246.

75 Z. Galili, A. Nenarokov, and L. Kheimson (eds.), Men'sheviki v 1917 godu [The Mensheviks in 1917], vol. 3. Ot kornilovskogo miatezha do kontsa dekabria [From the Kornilov Mutiny to Late December], Part 2: Ot Vremennogo Demokraticheskogo Soveta Rossiiskoi Respubliki do Kontsa Dekabria (Pervaia Dekada Oktiabria - Konets Dekabria) [From the Provisional Democratic Council of the Russian Republic to Late December], Moscow: ROSSPEN, 1997, pp. 580-581. 
cooperatives, trade unions, and academic institutions. The committee resolved in favour of bicameralism, with a majority of 11 against 7 votes. $^{76}$

Unlike the number of chambers, a cabinet answerable to the parliament was part of the moderate consensus. Yet the status of its head and the head of the Russian republic (after the KDs abandoned the slogan of constitutional monarchy in 1917) remained contested. Even though liberal legal scholars tended to see a republic with a president elected by the people and not the parliament as more democratic, ${ }^{77}$ the KD Party unanimously included the institution of a president to be elected through the parliament and governing through an answerable cabinet into its programme in March $1917 .^{78}$ The president's own answerability remained unclear. Nol'de, for instance, was campaigning for a politically non-answerable head of state as late as August 1917. ${ }^{79}$ The SRs Magerovskii and Vishniak rejected the institution of a president altogether, suggesting a collegial body fully answerable to the parliament instead. The former viewed the soviets of workers' and soldiers' deputies as such bodies, while the latter appealed to the example of Switzerland in which canton councils (sovety) ${ }^{80}$ were answerable to assemblies. ${ }^{81}$

Although official discussions of Russia's parliamentary system continued in the city of Petrograd until the dissolution of the Constituent Assembly, the establishment of a Bolshevik-Left SR government in late October 1917 reflected the growing popularity of leftist anti-parliamentarism. The discussions at the first Congress of the Left SRs (Petrograd, 19-28 November 1917), the new radical socialist party, were emblematic. The congress rejected the draft resolution, which called for a federative republic with a universally elected, unicameral

76 A. N. Medushevskii (ed.), Konstitutsionnye Proekty v Rossii XVIII - Nachala XX Veka [Constitutional Projects in Russia of the Eighteenth - Early Twentieth Century], Moscow: ROSSPEN, 2010, pp. 587-591.

77 Kotliarevskii, "Predposylki Demokratii" [1905], pp. 559-560.

78 O. N. Lezhneva (ed.), S’ezdy i Konferentsii Konstitutsionno-Demokraticheskoi Partii, 19051920 gg. [Congresses and Conferences of the Constitutional-Democratic Party], vol. 3, Part 1: 1915-1917 gg., Moscow: ROSSPEN, 2000, p. 400.

79 B. E. Nol'de, Uchreditel'noe Sobranie i Ego Zadachi: Rech'v Sobranii Grazhdan Goroda Rannenburga, Riazanskoi Gubernii 14 Avgusta 1917 goda [The Constitutent Assembly and Its Objectives: Speeach at the Gathering of Citizens of the Town of Rannenburg, Ryazan Province, 14 August 1917], Petrograd: K-vo Ogni, 1917, pp. 23-24.

80 Sokolov described the Swiss system as non-parliamentary and approaching direct democracy, see Sokolov, Parlamentarizm: Opyt Pravovoi Teorii Parlamentskogo Stroia, pp. 411, 414-416, 421-423.

81 Erofeev, Partiia Sotsialistov-Revoliutsionerov: Dokumenty i Materialy, 1900-1925 gg., vol. 3, Part 1: Fevral'-oktiabr' 1917 [February-October 1917], pp. 412-414; Magerovskii, Uchreditel'noe Sobranie i Ego Zadachi, pp. 24-25. 
parliament. Instead, it adopted the resolution proposed by Magerovskii, which foregrounded the messianic role of the Russian people in facilitating alternative modernity by "destroying the yoke of class slaughter and struggle among modern people". In order to do so, the toiling people had to take the power without sharing it with other classes, thereby establishing its dictatorship both in the centre and locally and rule the country through its class organizations during the continuous social revolution. The Central Executive Committee of Representatives from the Congress of All Soviets was to be recognized as the supreme legislative authority, while the Council of State Commissars, which it formed, would become the executive body responsible to the committee. ${ }^{82}$ Such a system, with some changes in the names of the bodies and formal distribution of competence, was soon formally established in Soviet Russia.

Yet the main anti-parliamentary parties - the Bolsheviks and the Left SRs did not make up a majority in the All-Russian Constituent Assembly even after their government ensured the exclusion of non-socialist deputies. Chernov, who was elected chairman, defended the slogan of a federative democratic republic in his opening speech on 5 January 1918. The Bolshevik Nikolai Ivanovich Bukharin, who defended Soviet rule, claimed that the Bolsheviks declared "war on the bourgeois-parliamentary republic" and aspired to create the "great Soviet Republic of Toilers" in Russia. Responding to the Menshevik declaration on establishing a democratic republic based on universal and proportional elections, put forward by Iraklii Georgievich Tsereteli, the Bolshevik Ivan Ivanovich Skvortsov-Stepanov asserted that for a Marxist there was no popular will but only that of a class and called parliamentary bodies mere idols. The moderate socialist majority, however, predominated and did not recognize Soviet rule. After the Bolsheviks and the Left SRs staged a walkout, the Constituent Assembly proclaimed the Russian Democratic Federative Republic early on 6 January 1918, yet the Soviet government dissolved the assembly the same day. ${ }^{83}$

82 Ia. V. Leont'ev (ed.), Partiia Levykh Sotsialistov-Revoliutsionerov: Dokumenty i Materialy, 1917-1925 gg. [The Party of Left Socialist-Revolutionaries: Documents and Materials], vol. 1: Iul’ 1917 g.-mai 1918 g. [July 1917-May 1918], Moscow: ROSSPEN, 2000, pp. 148-150.

83 T. E. Novitskaia, Uchreditel'noe Sobranie, Rossiia, 1918 g.: Stenogramma i Drugie Dokumenty [The Constituent Assembly, Russia, 1918: Verbatim Report and Other Documents], Moscow: Izd. Rossiiskogo otkrytogo un-ta, 1991, pp. 75, 77-78, 90, 115, 160. 


\section{Conclusion}

The discussions among Russian intellectuals demonstrated that there was no single understanding of a parliament's main functions and hence also its role in the country's government and design. At the same time, they demonstrated several points of connection between otherwise distant political positions. The importance of the state connected both liberals and rightists, with the establishment (or non-establishment) of a parliament presumably boosting the state's efficiency. Increasingly, a state-centred version of Russian nationalism was also adopted by socialists, with the ultimate slogan of turning Russia into a nationally defined, albeit ostensibly class-based, avant-garde of alternative modernity. Diversity management and decentralization proved especially important for liberals and socialists, who nevertheless did not agree on how a parliament could feature in them. The non-parliamentary approach to decentralization proved victorious, as the Bolshevik-Left SR government did create a Russian federative republic, featuring national autonomy, despite rejecting parliamentarism and the Bolsheviks' earlier suggestions for a unitary state. ${ }^{84}$

Ironically, the importance of the state eclipsed the need for a representative government even among parliamentarism's once vocal supporters. Although during the Russian Civil War (1918-1922) the slogan of reconvening the AllRussian Constituent Assembly was repeatedly voiced by various anti-Bolshevik groups - with plans for Ukrainian, Siberian, and other constituent assemblies as well as practices of delegated and elected "parliaments" in Transcaucasia, Ukraine, Siberia, and the Russian Far East - no major parliamentary developments occurred in the territories controlled by the Whites from 1918 to 1920. Many of the anti-Bolshevik leaders came to support one-man rule, be it reinstated monarchy or temporary dictatorship, and Sokolov himself joined the government of Anton Ivanovich Denikin, one such dictator.

The Soviet anti-parliamentary system also proved short-lived. Anarchists and soon the Left SRs refused to recognize the Bolshevik-dominated regime as class dictatorship. Furthermore, anti-parliamentarism was formally abandoned in 1936 with the adoption of the new Soviet Constitution, which introduced a Soviet "parliament" - the Supreme Soviet with two chambers. Although few had illusions about the party control over the institution, in the 1950s the delegation of the Supreme Soviet was admitted into the Inter-Parliamentary Union, marking the formal participation of the Soviet Union in the global parliamentary modernity.

84 For more on the subject, see T. Penter and I. Sablin, "Soviet Federalism from Below: The Soviet Republics of Odessa and the Russian Far East, 1917-1918”, Journal of Eurasian Studies 11 (2020) 2, pp. 40-52. 